\title{
The identification of outstanding potato cultivars using multivariate methods
}

\author{
Delfina de J. Pérez', Andrés González ${ }^{1}$, Jaime Sahagún ${ }^{2}$, Luis M. Vázquez', \\ Antonio Rivera ${ }^{3}$, Omar Franco', and Aurelio Domínguez ${ }^{1}$ \\ ${ }^{1}$ Centro de Investigación y Estudios Avanzados en Fitomejoramiento, Universidad Autónoma del Estado de \\ México, Toluca, Estado de México, México. Apartado postal 435. \\ 2 Departamento de Fitotecnia, Universidad Autónoma Chapingo, Chapingo, Estado de México, México. \\ ${ }^{3}$ Programa Nacional de Papa, Instituto Nacional de Investigaciones Forestales, Agrícolas y Pecuarias
} (INIFAP), Metepec, Estado de México, México.

\begin{abstract}
D.J. Pérez, A. González, J. Sahagún, L. M. Vázquez, A. Rivera, O. Franco, and A. Domínguez. 2009. The identification of outstanding potato cultivars using multivariate methods. Cien. Inv. Agr. 36(3):391-400. The evaluation and selection of potato (Solanum tuberosum) cultivars for commercial production in the high valleys of Mexico are important for plant breeding, seed production, and the generation of technology. In this work, ten potato cultivars from five different environments in Mexico were evaluated to determine the proportion of genetic variation contained within each. The potatoes were sown in a completely randomized complete block design. Heritability was determined to be between $53 \%$ and $83 \%$, suggesting that there is genetic variability among the potato cultivars that might be agronomically important. According to the additive main effects and multiplicative interaction (AMMI) model, the highest tuber yields were obtained at the locality named "Raíces" in the 2004 and 2005 growing seasons. In those production seasons, the best cultivars that positively correlated with each locality were 779040, 776943, Alpha, and Gigant with yields of 21.18, 21.97, 23.57, and 25.04 tha $^{-1}$, respectively. The main components and cluster analyses classified the potato cultivars into three groups. Group 1 included cultivars 777091, Zafiro, Atlantic, and 7718335, each having low yields. Group 2 included cultivars 676002, 779040, 750660, 776943, and Alpha; each had yields that were higher than the general mean, but lower than the Gigant cultivar (Group 3). The Gigant cultivar had the highest tuber yield as well as the highest mean tuber weight per plant, the largest tuber diameter, and tallest tuber lenght.
\end{abstract}

Key words: AMMI model, cluster analysis, principal component analysis, Solanum tuberosum.

\section{Introduction}

A thorough understanding of the relationship between the crop and the environment has

Received 25 November 2008. Accepted 30 April 2009.

Corresponding author: djperezl@uaemex.mx helped to increase potato (Solanum tuberosum L.) productivity. Information regarding the differences and the similarities of the cultivars, and the importance of the interaction between the cultivar and environment, allows for further refinement of genetic improvements even between growing seasons and in heterogeneous districts with different systems of production. Genotype- environment interaction (GEI) can 
be defined as the difference between the phenotypic value and the value expected from the corresponding genotypic value and environment values, so GEI is the variation caused by the joint effects of genotypes and environments. A statistically significant GEI reflects changes in the magnitude of the differences between a cultivar's relative performances and, more specifically, between changes in the environmental ranges of the cultivars. This metric, however, reduces some possible selection progress and it makes the recommendation of agronomically higher genotypes difficult. A more appropriate GEI analysis and interpretation can enable the identification of mega-environments, the identification of cultivars with wide or specific adaptations that can contribute to an increase in farmers' incomes, and the definition of more objective strategies for genetic improvement and selection (Rodríguez et al., 2005; Yan and Kang, 2003; Crossa et al., 1990).

Multivariate statistical methods have been used to identify outstanding genotypes and to study phenotypic diversity. For example, the principal component analysis (PCA), the analysis of the of additive main effects and multiplicative interaction (AMMI) model, and cluster analysis have been used for these purposes. AMMI analysis has the advantage of allowing for the graphic interpretation of the responses of the cultivars, the environments, and the GEI (Gauch, 2006; Zobel et al., 1988). In AMMI analysis, more than $55 \%$ of the sum of the GEI squares can be captured in the first two main components (Parga et al., 2005; Rodríguez et al., 2005; Abalo et al., 2003), resulting in a lower contribution from the residual variance in the biplot graphs.

Information regarding potato cultivars that can be recommended as candidates for commercial sowing is scarce; specifically, little is known with regards to their genetic diversity, stability, and their responses to the environmental conditions that characterize the high lands of México. The objective of this study was to identify the most outstanding potato cultivars, according to the components of variance and heritability using multivariate methods, and to make recommendations for commercial sowing, genetic improvement, and technology generation in the potato industry.

\section{Materials and methods}

\section{Districts}

This study was conducted in five different agricultural environments in Mexico State, Mexico. Four experiments were established in the dryland zones of the Raíces district, located in the municipalities of Zinacantepec and Metepec. The dry-land zones are defined by their rainfall regimes in the 2004 and 2005 spring-summer precipitation cycles. The fifth experiment was conducted under irrigation conditions in the 2005 winter-fall cycle in San Francisco Oxtotilpan, located in the municipality of Temascaltepec.

The Raíces district is located at 3,550 $\mathrm{m}$ above sea level (a.s.l.), and has a mean annual temperature of $9^{\circ} \mathrm{C}$. The region is characterized by sandy loam soils (Andosol) that are very rich in organic matter. Metepec is located at 2,606 m a.s.l., with a mean annual temperature of $13^{\circ} \mathrm{C}$. The soils at Metepec are deep and considered to be fertile andosolic. San Francisco is located at 2,613 m a.s.l., with a mean annual temperature of $20^{\circ} \mathrm{C}$. The soils in this region are sandy clay vertisol soils that receive $1,200 \mathrm{~mm}$ of mean annual rainfall. In the "Raíces" district the soil $\mathrm{pH}$ is 5.0, while in San Francisco and Metepec the soils have a $\mathrm{pH}$ of 5.5 and 6.5 , respectively (Chauvet et al., 2004; Borboa, 1999; Castro et al., 1999).

\section{Potato cultivars}

Ten minituber potato cultivars were used in this study. Seven cultivars were obtained from the Instituto Nacional de Investigaciones Forestales, Agrícolas and Pecuarias (INIFAP) (non-commercial cultivars or clones: 777091, 7718335, 750660, 779040, 'Zafiro', 676002, and 776943), and three cultivars came from El Rancho La Providencia, located in Calimaya, State of México (commercial cultivars: Alpha, Atlantic, and Gigant). There were no significant differences in the survival or mortality of the seedlings from different genetic stock in the five experiments, 
and the same number of plants was obtained (on average) in each experimental unit.

\section{Evaluated parameters}

Each experimental plot had three $0.90 \mathrm{~m} \times 1.8 \mathrm{~m}$ ridges, but only the central ridge was evaluated. Ten minitubers were planted with a spacing of $0.20 \mathrm{~m}$ in each ridge. For evaluation, ten plants were selected and the following variables were measured: plant height (AP) from the base of the main stem to the apex, number of stems (TA), number of tubers per plant (TU), tuber weight per plant (PTP), width of the tubers (DT), tuber length (LT), and tuber yield (PT).

\section{Statistical package}

A randomized complete block design was used with four replicates per environment. The components of variance and heritability were estimated using the environment, the cultivars, and the interaction between the environments and cultivars as random factors. The Agrobase 21 statistical pack and SAS Proc Varcomp (SAS Institute, Cary, NC, USA) were used (Annicchiarico, 1997).

The potato is an autogamous tetraploid species that generates genetically identical progenies when it is propagated vegetatively. Therefore, the variance exhibited between the cultivars may be used as an estimator of the total genetic variance (Estrada, 2000). In addition, if the variance within cultivars is assumed to be zero, then, with the expectation of the mean square of the analysis of variance, the heritability may be estimated in the strict sense $\left(\mathrm{h}^{2}\right)$ as:

$$
\mathrm{h}^{2}=100 \sigma_{\mathrm{G}}^{2} /\left[\sigma_{\mathrm{G}}^{2}+\sigma_{\mathrm{GA}}^{2} / \mathrm{a}+\sigma_{\mathrm{E}}^{2} / \mathrm{ra}\right]
$$

where $\sigma_{\mathrm{G}^{2}}+\sigma_{\mathrm{GA}}^{2} / \mathrm{a}+\sigma_{\mathrm{E}}^{2} /$ ra represents the variances between cultivars of the GEI interaction and the combined error. In addition, a and $r$ are the environments and repetitions per environment, respectively (González et al., 2006).
The tuber yield per hectare was analyzed using the additive main effects and multiplicative interaction (AMMI) model to study the treatment structure related to the environments, the cultivars, and their interaction simultaneously (Parga et al., 2005; Rodríguez et al., 2005; Zobel et al., 1988). The following model was used:

$$
\mathrm{Y}_{\mathrm{ge}}=\mu+\alpha_{\mathrm{g}}+\beta_{\mathrm{e}}+\sum \lambda_{\mathrm{n}} \delta_{\mathrm{en}} \gamma_{\mathrm{gn}}+\rho_{\mathrm{ge}}
$$

Where $\mathrm{Y}_{\mathrm{ge}}$ is the yield of cultivar $\mathrm{g}$ in environment $\mathrm{e}, \mu$ is the grand mean, $\alpha_{\mathrm{g}}$ is the mean deviation of the genotype $g$ and the grand mean, $\beta_{\mathrm{e}}$ is the mean deviation between the environment e and the grand mean, $\gamma_{\mathrm{gn}}$ is the square root of the value of the characteristic axis $n$ of the PCA analysis, $\delta_{\mathrm{en}} \mathrm{y} \gamma_{\mathrm{gn}}$ are the genotype and environment PCA scores for the PCA axis n, and $\rho_{\mathrm{ge}}$ is the model residue (Gauch et al., 2008).

In the AMMI analyses of variance, the F tests applied to each variation source of interest, and the biplot graphs corresponding to the AMMI1 and AMMI2 models were calculated using the Vargas and Crossa programs (2000), which run on the SAS statistical package for Windows.

The principal components (varimax type rotation) and clusters (squared Euclidian distance), as described by Johnson and Wichern (1999) and by González et al. (2006), were used to study the structure of the treatments in the biplot based on all of the variables evaluated and to determine the similarity or difference between potato cultivars, respectively. The data and graphics analyses corresponding to both methodologies were conducted using Statgraphics (Statpoint Technologies, Inc. Warrenton, VA, USA).

\section{Results and discussion}

Modeling the additive main effects and multiplicative interactions (AMMI)

A significant effect $(\mathrm{p} \leq 0.01)$ was obtained for environments (E), cultivars (G), GEI, and for the first three principal components of the seven parameters evaluated in this study (Table 1). The first two components explained $72-85 \%$ of 
the GEI in the seven parameters evaluated. The heterogeneity among the districts was correlated first two principal components explained more than $55 \%$ of the GEI.

Table 1. Mean squares for the seven characters evaluated with the AMMI model in the ten potato varieties planted in five environments in the State of Mexico in 2004 and 2005.

\begin{tabular}{|c|c|c|c|c|c|c|c|c|}
\hline Source of variation & d.f. & $\begin{array}{c}\text { Plant } \\
\text { height } \\
\mathrm{cm}\end{array}$ & $\begin{array}{c}\text { Stems/ } \\
\text { plant } \\
\text { no. }\end{array}$ & $\begin{array}{c}\text { Tubers } \\
\text { /plant } \\
\text { no. } \\
\end{array}$ & $\begin{array}{c}\text { Tuber weight / } \\
\text { plant } \\
\mathrm{g} \\
\end{array}$ & $\begin{array}{c}\text { Tuber width } \\
\mathrm{cm}\end{array}$ & $\begin{array}{c}\text { Tuber length } \\
\mathrm{cm}\end{array}$ & $\begin{array}{c}\text { Tuber yield } \\
\mathrm{t} \mathrm{ha}^{-1}\end{array}$ \\
\hline Environments (E) & 4 & $5774.0 * *$ & $34.61 * *$ & $287.6^{* *}$ & $263860 * *$ & $21.87 * *$ & $38.67 * *$ & $1287 * *$ \\
\hline Replicates / E & 15 & $33.4 \mathrm{~ns}$ & 0.60 & 6.6 & 25556 & 0.25 & 0.50 & 54 \\
\hline Cultivars (G) & 9 & $1000.9 * *$ & $4.41 * *$ & $103.2 * *$ & $118060^{* *}$ & $2.15^{* *}$ & $4.73 * *$ & $422 * *$ \\
\hline GEI & $(36)$ & $261.9 * *$ & $0.89 * *$ & $37.5^{* *}$ & $58754 * *$ & $0.72 * *$ & $1.32 * *$ & $175^{* *}$ \\
\hline Principal component 1 & 12 & $381.6 * *$ & $1.64 * *$ & $69.4 * *$ & $94674 * *$ & $1.15 * *$ & $1.99 * *$ & $330 * *$ \\
\hline Principal component 2 & 10 & $314.2 * *$ & 0.71 & 31.7 & 50183 & 0.76 & 1.07 & 156 \\
\hline Principal component 3 & 8 & $187.6^{* *}$ & $0.56 * *$ & $17.8 * *$ & $45817 * *$ & $0.40 * *$ & $1.20 * *$ & $81 * *$ \\
\hline Principal component 4 & 6 & $34.6 \mathrm{~ns}$ & $0.14 \mathrm{~ns}$ & $9.6^{*}$ & $18441 \mathrm{~ns}$ & $0.19 \mathrm{~ns}$ & $0.57 \mathrm{~ns}$ & $20 \mathrm{~ns}$ \\
\hline Pooled error & 135 & 25.8 & 0.19 & 4.2 & 10485 & 0.17 & 0.33 & 23 \\
\hline Heritability $\left(h^{2}\right), \%$ & & 73.2 & 83.5 & 70.7 & 53.0 & 61.1 & 73.6 & 59.7 \\
\hline Coefficient of variation, $\%$ & & 14.4 & 17.6 & 2.8 & 30 & 9.46 & 10.53 & 25.6 \\
\hline
\end{tabular}

with differences in altitude, soil, and temperature. The significant differences $(\mathrm{p} \leq 0.01)$ obtained between the cultivars detected for the seven variables (Tables 1 and 2) are related to the wide genetic variability existing between each. The estimated heritabilities, in the strict sense, for plant height, stems per plant, tubers per plant, tuber weight per plant, tuber diameter, tuber length, and yield per hectare, were $73.2,83.5,70.7,53.0$, $61.1,73.6$, and $59.7 \%$, respectively. These results showed a genetic variability among cultivars that may be useful for a program of genetic improvement to promote the yield, either directly or indirectly, by enhancing the tuber characteristics. According to the statistical GEI significance ( $\mathrm{p}$ $\leq 0.01$ ), the cultivar performance in the different environments varied for the seven variables. Therefore, the better-adapted cultivars may be identified as those reported previously by Parga et al., (2005), Rodríguez et al., (2005) and Abalo et al. (2003). These authors found significant differences ( $p \leq 0.01)$ among the different environments, among the cultivars, and in the GEI; the
The AMMI graphs showing the average tuber yield and the first principal component (PC1) allowed for the classification of the environments in two groups (Figure 1). The first group was included in the "Raíces" district in both years (R04 and R05). In this district, the highest tuber yields were obtained and their correlation with PC1 was positive; thus, both years represented the best environments. Potatoes are cultivated in cold temperature conditions, which can explain the high yields in the "Raíces" district. In the second group, the Metepec were detected in both years (M04 and M05) and San Francisco in only one (SF05). The average of tuber yields of all the cultivars in San Francisco were lower than the general mean $\left(18.7 \mathrm{t} \mathrm{ha}^{-1}\right)$ and had a negative correlation with the PC1. These results suggest that potatoes could be used as a test crop specifically in the Raíces district to identify outstanding cultivars, increase minituber seeds, or improve high yield cultivars that are tolerant to low temperatures. 


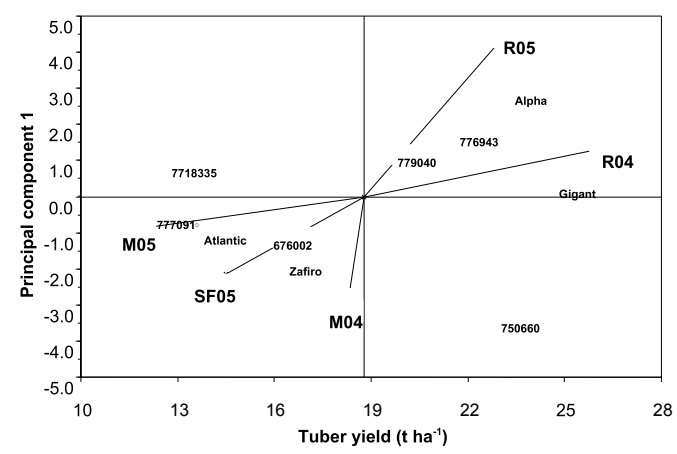

Figure 1. Representation of the tuber yield of potato (Solanum tuberosum) and the first principal component of the ten cultivars in five environments according to the AMMI analysis.

The AMMI biplot also allowed for the classification of the cultivars into two groups. The cultivars Gigant, Alpha, 776943, and 779040 were identified in the first group, with the highest mean yield, that is between 21.18 and $25.04 \mathrm{t} \cdot \mathrm{ha}^{-1}$ and a positive correlation with the PC1. This suggests that this group of cultivars was better adapted to the "Raíces" district in both years. Except for $750660\left(23.30 \mathrm{t} \cdot \mathrm{ha}^{-1}\right)$, the second group of cultivars had lower yields than the general mean and correlated negatively with the PC1 in San Francisco and Metepec (Figure 1). These results suggested that the study of the specific adaptation should receive more attention, as proposed previously for similar conditions (Rodríguez et al., 2005; Yan and Kang, 2003: Crossa et al., 1990). In this context, Bonierbale et al. (2004) recommended the development of stable cultivars adapted to marginal heterogeneous environments to reduce the amount of supplies applied during cultivation.

The graphs of the cultivars and the environments in the PC1 and PC2 plane (Figure 2) show that the Atlantic cultivar and the 750660 and 779040 clones have a lower GEI, due to their smaller values. The Zafiro cultivar had a negative inter- action with axis 1 , but this interaction was positive in the Gigant cultivars and in the 7718333 and 776943 clones, suggesting that the Gigant cultivar and 7718833 and 776943 clones were better adapted to the R05 and MO5 environments. The 777091 clone had a positive interaction with PC2 $(\mathrm{p}<0.05)$ and it was highly affected by the M04, M05, and R05 environments. The Alpha cultivar, with positive and significant interactions $(\mathrm{p}<0.05)$ in RO4 and RO5 (36.0 and $39.5 \mathrm{t} \cdot \mathrm{ha}^{-1}$, respectively), had the best adaptation in both environments. Clone 750660 responded better to MO4 and SF05 (30.1 and $\left.27.0 \mathrm{t} \cdot \mathrm{ha}^{-1}\right)$, but its interaction with PC2 was statistically nonsignificant $(\mathrm{p}>0.05)$. According to Yan and Kang (2003), R05 should be considered as the best environment, as it has the longest vector, while M04 represents the best average performance of the environments. The superiority of the Alpha and Gigant cultivars, the most commonly planted in the area of this study, was previously reported by Cadena et al. (1999) who evaluated potatoes from minitubers in the States of México and Tlaxcala. Cadena et al. (1999) concluded that the Alpha cultivar produced from 20.25 to $39.88 \mathrm{t} \cdot \mathrm{ha}^{-1}$, while Gigant yielded from 17.0 to $53.0 \mathrm{t} \cdot \mathrm{ha}^{-1}$. In another study, Alpha had a mean yield of $45.54 \mathrm{t} \cdot \mathrm{ha}^{-1}$ (Rojas et al., 1978). 


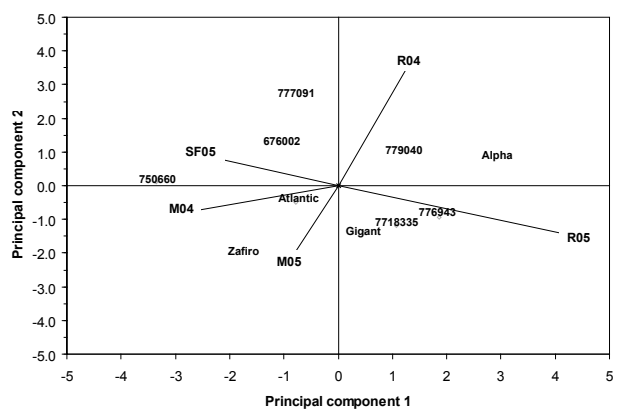

Figure 2. Representation of the first two principal components of ten cultivars of potato (Solanum tuberosum) and the five environments, according to the AMMI (additive main effects and multiplicative interaction) analysis.

\section{Analysis of clusters}

When considering a squared Euclidean distance of 20 units, the cultivars were classified into three groups. In the first group (Group 1), the clones 777091 and 7718335 , and the cultivars Zafiro and Atlantic were included. This group had a lower average yield $\left(14.23\right.$ tha $\left.^{-1}\right)$, a lower tuber weight per plant $(271.5 \mathrm{~g})$, and a lower number of stems (2.18) and tubers per plant (6.24). Group 2 was formed by clones 676002, 779040, 750660, and 776943, and the cultivar Alpha, with an average yield (PT) of $21.28 \mathrm{t} \cdot \mathrm{ha}^{-1}$. The clones 779040, 750660, 776943 and Alpha cultivar had higher yields than the general mean, but these yields were lower than Gigant, which was outstanding in plant height $(40.36 \mathrm{~cm})$, tuber weight per plant (PTP) $(381.27$ g), and tuber per plant (TU) (9.74), and number of stems (TA) (2.88). Group 3 included only Gigant, the cultivar with the highest yield (25.04 $\left.\mathrm{t} \cdot \mathrm{ha}^{-1}\right)$ and with high means in diameter (5.12 $\mathrm{cm})$, tuber length $(6.25 \mathrm{~cm})$, and in PTP (417.66 g) (Figure 3; Table 2). Parga et al. (2005) reported results similar to the observations of this study, classifying Alpha (30.8 $\left.\mathrm{t} \cdot \mathrm{ha}^{-1}\right)$ and Atlantic $\left(31.8 \mathrm{t}^{\mathrm{h}} \mathrm{ha}^{-1}\right)$ into different groups. Parga et al. (2005) also stated that both cultivars were developed in the Netherlands and the U.S.A.; the Alpha progenitors were Preferent $x$ Paul Kruger and the 'Atlantic' progenitors were Wauseon x B5141-6.

\section{Principal component analysis}

PC1 was defined predominantly by plant height (AP) and by the number of stems per plant (TA), which are variables associated with the plant dimensions. PC2, on the other hand, was determined by the variables associated to tuber yield. The biplot graphs (Figure 4) also suggest that an increase in potato production in this region could be achieved when promoting the expression of the per se yield, or when increasing the number of tubers (TU), PT, and PTP. The last approach is concurrent with the performance of Gigant, Alpha, and the 750660, 776943 and 779040 clones, which are clones and cultivars with the highest arithmetic averages in these variables. In addition to Gigant and Alpha, DT, LT, and PTP stood out. These results could be related to the way in which the plant breeder selects the clones with the heaviest, healthiest, tubers, which are also the largest in length and diameter. Because these variables are related, the result is selection for a higher yield per hectare. Based on the seven variables, the analysis of principal components and the cluster analysis classified the genotypes in the same manner, but the tuber weight per plant (PTP) and the tuber yield per hectare (PT) were the most influential variables in this group (Table 2, Figures 3 and 4).

In other studies, such as Rojas et al. (1978), Rousselle et al. (1999), and Estrada (2000), it has been concluded that the number of stems (TA) is correlated with the number of tubers (TU). It is therefore important to promote an increased number of stems, as this variable also influences tuber quality and yield per hectare. Rojas et al. (1978), Rousselle et al. (1999), and Estrada (2000) recorded three to ten stems per plant and Parga et al. (2005) counted from 3.32 to 5.95 stems per plant. The number of tubers is genetically controlled and depends on the number of stems per plant, with each stem producing between 2.5 and 4.5 tubers. In a study with 23 potato cultivars, Romero et al. (2003) recorded tuber weights per plant that were lower than $350 \mathrm{~g}$. Tuber length and diameter are positively and significantly correlated with each 
Table 2. Arithmetic means of the seven variables recorded in the ten potato cultivars evaluated in five environments in the State of México in 2004 and 2005.

\begin{tabular}{|c|c|c|c|c|c|c|c|}
\hline $\begin{array}{l}\text { Potato } \\
\text { cultivars }\end{array}$ & $\begin{array}{l}\text { Plant } \\
\text { height } \\
\mathrm{cm}\end{array}$ & $\begin{array}{l}\text { Stems } \\
\text { /plant } \\
\text { no. }\end{array}$ & $\begin{array}{l}\text { Tubers } \\
\text { /plant } \\
\text { no. }\end{array}$ & $\begin{array}{l}\text { Tuber weight / } \\
\text { plant } \\
\text { g }\end{array}$ & $\begin{array}{l}\text { Tuber width } \\
\mathrm{cm}\end{array}$ & $\begin{array}{l}\text { Tuber length } \\
\mathrm{cm}\end{array}$ & $\begin{array}{l}\text { Tuber } \\
\text { yield } \\
\mathrm{t} \mathrm{ha}^{-1}\end{array}$ \\
\hline \multicolumn{8}{|l|}{ Group 1: } \\
\hline 777091 & 30.61 & 2.51 & 8.04 & 225.16 & 3.92 & 5.04 & 13.28 \\
\hline 7718335 & 29.27 & 2.02 & 4.39 & 265.60 & 4.26 & 6.31 & 13.54 \\
\hline Atlantic & 28.04 & 2.04 & 5.58 & 245.85 & 4.32 & 5.25 & 13.61 \\
\hline Zafiro & 32.89 & 2.16 & 6.96 & 349.53 & 4.58 & 5.24 & 16.50 \\
\hline Mean & 30.29 & 2.18 & 6.24 & 271.53 & 4.27 & 5.46 & 14.23 \\
\hline \multicolumn{8}{|l|}{ Group 2: } \\
\hline 750660 & 31.61 & 2.84 & 12.63 & 416.31 & 4.43 & 5.31 & 23.29 \\
\hline 779040 & 44.93 & 2.45 & 8.88 & 364.39 & 4.41 & 5.00 & 21.18 \\
\hline Alpha & 41.39 & 2.61 & 9.42 & 438.08 & 4.56 & 5.84 & 23.57 \\
\hline 676002 & 36.59 & 3.11 & 8.40 & 302.81 & 4.04 & 5.17 & 16.40 \\
\hline 776943 & 47.29 & 3.39 & 9.40 & 384.80 & 4.32 & 5.22 & 21.97 \\
\hline Mean & 40.36 & 2.88 & 9.74 & 381.27 & 4.35 & 5.30 & 21.28 \\
\hline \multicolumn{8}{|l|}{ Group 3: } \\
\hline Gigant & 28.59 & 2.13 & 8.91 & 417.66 & 5.12 & 6.25 & 25.04 \\
\hline
\end{tabular}

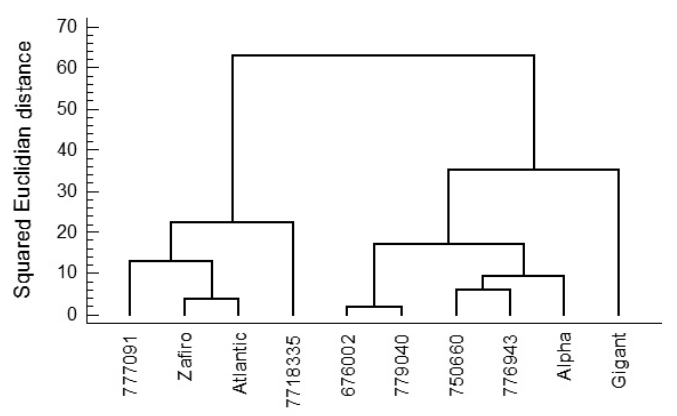

Figure 3. The dendrogram obtained with Ward's method (Johnson and Wichern, 1999) using the squared Euclidian distance, representing ten cultivars of potato (Solanum tuberosum).

other, and with the yield per hectare. In addition, both variables are highly important in the commercial market. For fresh consumption, tubers between 4.5 and $5.0 \mathrm{~cm}$ are required, while the fried food industry needs tubers larger than $6.5 \mathrm{~cm}$. In this study eight of the ten cultivars were classified in the first category (Macías et al., 1997) as they reported lengths between 5.0 and $5.84 \mathrm{~cm}$, meaning that they are appropriate for the fresh consumption market. On the other hand, only Gigant and 7718335 might be considered for fried food industry due their tuber length was reported between 6.25 and $6.31 \mathrm{~cm}$, respectively.

The AMMI model allowed for the differentiation of environments (E), cultivars (G), and of the genotype - environment interaction (GEI). 


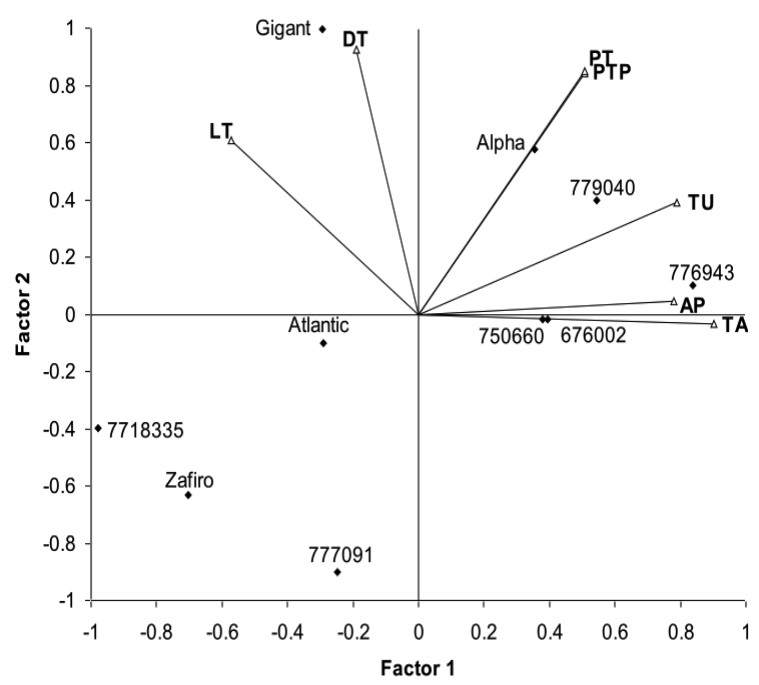

Figure 4. Representation of the first two principal components of seven variables recorded in ten cultivars of potato (Solanum tuberosum) evaluated in the five environments in the State of México.

For the seven variables evaluated, the first two principal components captured $72-85 \%$ of the GEI sum of squares. The vectors associated with Raíces in both years were the longest and were useful in identifying higher yielding genotypes. This district could be used to identify outstanding cultivars, to increase minituber seeds, and to obtain high yield cultivars that are tolerant to low temperatures. The analysis of the principal components and the clusters classified the cultivars in three groups and Atlantic, Alpha, and Gigant were included in different groups. The cultivars Gigant and Alpha and the clones 750660,779040 and 776943 yielded between 21.2 and $25.0 \mathrm{t}^{\mathrm{h}} \mathrm{ha}^{-1}$ and also stood out in the number of stems and tubers per plant, weight, length, and in the diameter of the tuber on each plant.

\section{Acknowledgements}

The authors would like to thank the Instituto Nacional de Investigaciones Forestales, Agrícolas y Pecuarias (INIFAP) and Rancho La Providencia (Calimaya, Estado de México) for the donation of ten potato cultivars used in this study. The authors are very grateful to Antonio Rivera Peña, Sergio Aguirre Vázquez and Adán Vázquez Reyes for providing the land and the agronomic management for the five trials conducted in 2004 and 2005. 


\section{Resumen}

D.J. Pérez, A. González, J. Sahagún, L. M. Vázquez, A. Rivera, O. Franco y A. Domínguez. 2009. Identificación de cultivares sobresalientes de papa empleando métodos multivariados. Cien. Inv. Agr. 36(3):391-400. La evaluación y elección de cultivares de papa (Solanum tuberosum L.) recomendados o candidatos a siembra comercial en los valles altos de México es importante para su mejoramiento genético, producción de semilla y generación de tecnología. Por esta razón se evaluaron diez cultivares en cinco ambientes del estado de México, México, para identificar los más sobresalientes usando métodos multivariados, y para determinar la proporción de la variabilidad genética que está presente en esta especie. Se usó un diseño de bloques completos al azar con cuatro repeticiones por ambiente. En este estudio se estimaron heredabilidades entre 53.0 y $83.5 \%$; estos resultados indican que existe variabilidad genética entre cultivares que es de importancia agronómica. Según el modelo de efectos principales aditivos e interacción multiplicativa (AMMI), la localidad de Raíces en 2004 y 2005 fueron los ambientes con los mayores rendimientos de tubérculo; los cultivares más sobresalientes y con correlación positiva con esta localidad en ambos años fueron 779040 , 776943, 'Alpha' y 'Gigant' (21.18; 21.97; 23.57 y $\left.25.04 \mathrm{t} \cdot \mathrm{ha}^{-1}\right)$. Los análisis de componentes principales y de conglomerados clasificaron los cultivares en tres grupos: grupo 1, con 777091, Zafiro, 'Atlantic' y 7718335, los cultivares de menor rendimiento; grupo 2, con 676002, 779040, 750660, 776943 y 'Alpha', con rendimientos mayores que la media general pero inferiores a 'Gigant' (Grupo 3), el cultivar de mayor producción y medias altas en peso de tubérculo por planta, diámetro y longitud de tubérculo.

Palabras clave: Análisis de componentes principales, análisis de conglomerados, modelo AMMI, Solanum tuberosum.

\section{References}

Abalo, G., J.J. Hakize, R. El-Bedwy, and E. Adipala. 2003. Genotype x environment interactions studies on yields of selected potato genotypes in Uganda. African Crop Science Journal 11:2 (Abstract).

Annicchiarico, P. 1997. Additive main effects and multiplicative interaction (AMMI) analysis of genotype-location interaction in variety trials repeated over years. Theor. Appl. Genet. 94:10721077.

Bonierbale, M., W. Amoros, J. Espinosa, E. Mihovilovich, W. Roca, and R. Gómez. 2004. Recursos genéticos de la papa: don del pasado, legado para el futuro. Suplemento Revista Lati- noamericana de la Papa 1:3-13.

Borboa, A.1999. Monografía de Temascaltepec. Instituto Mexiquense de Cultura, Gobierno del Estado de México. México, 239 pp.

Cadena, A., M. Díaz, H. López, T. Zavala, R. Flores, M. Villarreal, A. Rivera, O. Rubio, R. Rocha, H. Azpíroz, J. Rodríguez, A. Manzo, and S. Barrales. 1999. Evaluación de variedades de papa para producción de tubérculos-semilla en los estados de México y Tlaxcala. Revista Agricultura Técnica en México 25:97-105.

Castro, O.1999. Monografía Municipal de Metepec. Gobierno del Estado de México. Instituto Mexiquense de Cultura- Asociación Mexiquense de Cronistas Municipales A. C. Toluca, México, $123 \mathrm{pp}$.

Crossa, J., H.G. Gauch, Jr., and R.W. Zobel. 1990. 
Additive main effect and multiplicative interaction analysis of two international maize cultivar trials. Crop Science 30:493-500.

Chauvet, M., R. González, R. Barajas, S. Castañeda, and Y. Massieu. 2004. Impactos Sociales de la Biotecnología en el cultivo de la papa. Editorial Praxis. Universidad Autónoma Metropolitana, México, 289 p.

Estrada, N. 2000. La Biodiversidad en el Mejoramiento Genético de la Papa. CIP-PROINCACOSUDE-CID. La Paz, Bolivia, 372 p.

Gauch, H.G. 2006. Statistical analysis of yield trials by AMMI and GGE. Crop Science. 46:14881500.

Gauch, H.G. 2007. MATMODEL. Version 3.0. Open Source Software for AMMI and related analysis. Crop and Soil Science, Cornell University, Ithaca, NY 14853, 73 p.

Gauch, H. G., Piepho, P., and Annicchiarico, P. 2008. Statistical Analysis of yield trials by AMMI and GGE: Further considerations. Crop Science 48:866-889.

González, A., J. Sahagún, D. Pérez, A. Domínguez, R. Serrato, V. Landeros, and E. Dorantes. 2006. Diversidad fenotípica del maíz Cacahuacintle en el Valle de Toluca. Revista Fitotecnia Méxicana 29:255-261.

Johnson, R., and D. Wichern. 1988. Applied Multivariate Statistical Analysis. Second ed. Prentice Hall. NJ, USA, 607 pp.

Macías, L., L. Reyes, and F. Robles. 1997. Guía para cultivar papa en Aguascalientes. Folleto Técnico No. 13. INIFAP-Fundación Produce. Aguascalientes, México, 66 pp.
Parga, V., V. Zamora, V. González, S. García, and E. Villavicencio. 2005. Interacción genotipo por ambiente en clones de papa bajo riego en el Noroeste de México. Agricultura Técnica en México 31:55-65.

Rodríguez, J., J. Sahagún, H. Villaseñor, J. Molina, and A. Martínez. 2005. La interacción genotipo $\mathrm{x}$ ambiente en la caracterización de áreas temporaleras de producción de trigo. Agrociencia 39:51-64.

Rojas, E., J. Molina, and H. Angeles. 1978. Efecto del tamaño y número de brotes de tubérculo-semilla en el rendimiento y otros caracteres de la papa. Agrociencia 31:83-102.

Romero, C., H. Lozoya, and A. Hernández 2003. Adaptación por resistencia al tizón tardío (Phytophthora infestans (Mont.) de Bary) de genotipos de papa (Solanum tuberosum L.) en Toluca, México. Revista Chapingo Serie Horticultura 9:193-198.

Rousselle, P., Y. Robert, and J. Crosnier. 1999. La Patata. J. M. Mateo (Trad). Ediciones MundiPrensa, Madrid, España. 607 pp.

Vargas, M., and Crossa, J. (2000). The AMMI analysis and graphing the biplot. Biometrics and Statistics Unit. CIMMYT, Mexico, 39 p.

Yan, W., and M. Kang. 2003. GGEBiplot Analysis: A Graphical Tool for Breeders, Geneticists, and Agronomists. CRC Press LLC. Boca Raton, FI, USA, $276 \mathrm{pp}$.

Zobel, W., M. Wright, and H.G. Gauch, 1988. Statistical analysis of a yield trial. Agronomy Journal 88:388-393. 